BISNIS \& BIROKRASI: Jurnal Ilmu Administrasi dan Organisasi

Volume 28

Number 1 Volume 28 No. 1 (January 2021)

Article 1

June 2021

\title{
Factors Influencing Purchase Intention in Affecting Purchase Decision: A Study of E-commerce Customer in Greater Jakarta
}

Farida Komalasari

Antonny Christianto

Eko Ganiarto

Follow this and additional works at: https://scholarhub.ui.ac.id/jbb

Part of the E-Commerce Commons, and the Entrepreneurial and Small Business Operations Commons

\section{Recommended Citation}

Komalasari, Farida; Christianto, Antonny; and Ganiarto, Eko (2021) "Factors Influencing Purchase Intention in Affecting Purchase Decision: A Study of E-commerce Customer in Greater Jakarta," BISNIS \& BIROKRASI: Jurnal IImu Administrasi dan Organisasi: Vol. 28 : No. 1 , Article 1.

DOI: $10.20476 /$ jbb.v28i1.1290

Available at: https://scholarhub.ui.ac.id/jbb/vol28/iss1/1

This Article is brought to you for free and open access by the Faculty of Administrative Science at UI Scholars Hub. It has been accepted for inclusion in BISNIS \& BIROKRASI: Jurnal IImu Administrasi dan Organisasi by an authorized editor of UI Scholars Hub. 


\title{
Factors Influencing Purchase Intention in Affecting Purchase Decision: A Study of E-commerce Customer in Greater Jakarta
}

\author{
Farida Komalasari ${ }^{1}$, Antonny Christianto ${ }^{2}$, Eko Ganiarto ${ }^{3}$ \\ Faculty of Business, President University, Indonesia ${ }^{1,2,3}$ \\ farida_k@president.ac.id ${ }^{1}$, antonnychristianto@gmail.com² ${ }^{2}$,eganiarto@president.ac.id ${ }^{3}$
}

\begin{abstract}
This study aims to identify factors influencing purchase intention in affecting purchase decision of e-commerce customers in Greater Jakarta. This research employs survey by distributing questionnaires to 300 respondents in Greater Jakarta aged between 19 - 39 years old, who were selected by purposive snowball sampling technique. The data collected were analyzed by Structural Equation Model (SEM). This research reveals that perceived risk has a negative impact on purchase intention, while perceived benefit, trust, and brand image have a positive impact on purchase intention. Meanwhile, purchase intention has a positive impact on purchase decision for e-commerce customers. It is important to note that perceived benefit, trust, and brand image are strong drivers of purchase intention, which affect purchase decision. E-commerce companies may develop strategies to increase customer purchase decision by managing those variables.
\end{abstract}

Keywords: e-commerce, purchase decision, purchase intention, perceived risk, perceived benefit, trust, brand image.

\section{INTRODUCTION}

In recent years, the internet has been inseparable part of human life. In 2018, the United Nations' telecommunication agency announced that by the end of 2018, the total internet users will reach 3.9 billion people. This means that the total number of internet users has exceeded one half of the global human population. Indonesia, as one of the most populated countries in the world, significantly contributes to those numbers. A survey done by Polling Indonesia in cooperation with the Indonesian Internet Service Provider Association or "Asosiasi Penyelenggara Jasa Internet Indonesia" (APJII) shows that Indonesia has 171 million internet users from its total population of 264 million people. This is equivalent to $64.8 \%$ of Indonesia's total population (JakartaPost, 2019). Amongst the high volume of internet surfers, internet users in Indonesia are mostly the young generation, born 1980 s to the early 2000 s. Internet penetration for people aged 20-24 years old has reached $88.5 \%$, aged $25-29$ at $82.7 \%, 30-34$ at $76.5 \%$, and last but not least, 35-39 at 68.5\% (Detikinet, 2019). Furthermore, APJII stated that the top three provinces with the highest internet penetration are Bengkulu (85\%), West Sumatra (84.2\%), and Capital City of Jakarta $(80.4 \%)$. Aside from the top three provinces, other provinces with high internet users are West Java, Central Java, Bangka Belitung, Kepulauan Riau, and Jambi (Tempo.co.id, 2019).

The flabbergasting growth of the internet has increased the importance of e-commerce. According to Othman (2015), e-commerce stands for electronic commerce, which means to do business electronically. Electronic commerce includes all kinds of business or administrative transactions or exchange of information that is done by means of using any information and communication technology (Bisrat, 2019). The statistics for global retail e-commerce sales from the year 2014 until the year 2017 and its predicted sales growth from the year 2018 up to the year 2023 are shown in figure 1 in which the sales are presented in billion US Dollars.

Figure 2 shows the top 5 world retailers, which are Amazon.com, JD.com, Apple.com, Suning.com, and Walmart.com.

Amazon, the largest E-Commerce in the US and JD (Jing Dong), the largest E-Commerce in China, are the two top players. Amazon reaches 77 billion USD in sales, and JD is following with 61 billion USD. Combined with sales of Apple.com, Suning. com, and Walmart.com, those five companies have recorded global net sales of approximately 200 billion USD (Angelovska, 2019).

For Indonesia, The Indonesian Central Bank has released data revealing the total value of online transactions in Indonesia for 2018 which reached 77.766 trillion Indonesia Rupiah (Daniel, 2019). For comparison, Indonesia's gross domestic product, according to the Indonesian Central Bureau of Statistics, for the same period, is 14,837.4 trillion Rupiah (BPS, 2019). Hence, the total online transaction in Indonesia contributes $0.5 \%$ to the national GDP. This is a $151 \%$ rise compared to the last year total online sales of 30.942 trillion Indonesia Rupiah. For 2019, the Central Bank has recorded 8.204 trillion Rupiah transactions for the first month of the year (Daniel, 2019).

Purchase decision, according to Lovelock and Wirtz (2007), is the purchasing process of selecting, taking, and perceiving a service. There are three stages 
Figure 1. Retail E-commerce Sales Worldwide from 2014 to 2023

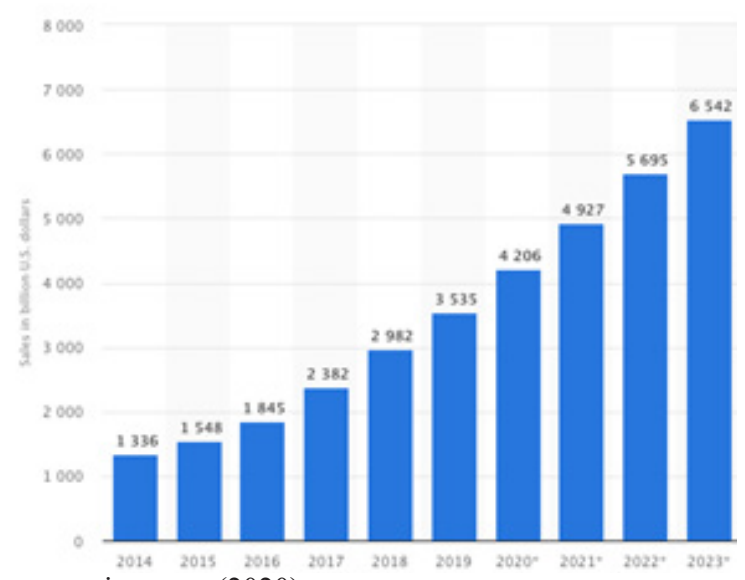

Source: statista.com (2020)

in the purchasing decision, which are pre-purchase, service encounter, and post-purchase. Pre-purchase happens when potential customers observe and evaluate their needs for product or services offered. Next, the service encounter stage is when customers and the business interacts to deliver the service. Last, the post-purchase stage is where customers evaluate their experience (Nugraha, Komalasari, \& Dethionia, 2018). A study done in Semarang by observing the E-Commerce Lazada shows that purchase decision is influenced by purchase intention (Puspitasari et

Figure 2. Top 5 Ranked World E-Retailers

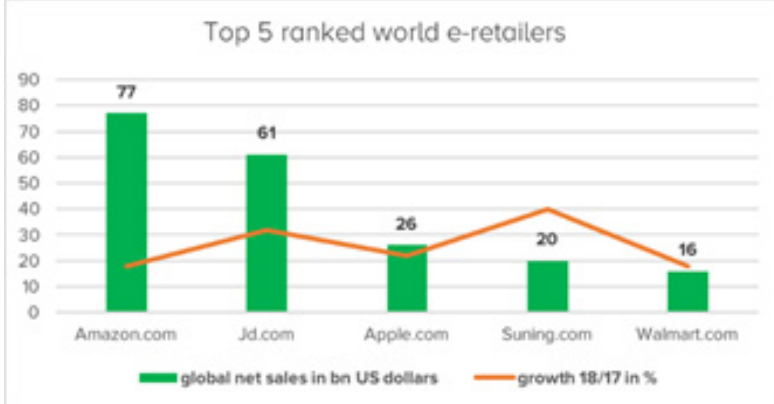

Source: Angelovska (2019)

al, 2018).

Kotler (2006) explained that purchase intention is the behavior of a consumer when they are interested in purchasing a product or service (Khairunnisa, Hafidhuddin, \& Tanjung, 2018). Perceived risk, perceived benefit, and trust are factors that have a positive and significant effect on the purchase intention of Traveloka consumers (Rachbini, 2018). Zamrudi, Suyadi, and Abdillah argued that brand image and trust also have a significant impact on purchase intention (Zamrudi, Suyadi, \& Abdillah, 2016). Hence, the authors have created a framework on how perceived risk, perceived benefit, trust, and brand image influence the purchase intention and how purchase intention influence purchase decision of e-commerce customers, especially in the Greater Jakarta area.

The total online retail transaction in Indonesia is predicted to reach 7.3 billion USD or $4.4 \%$ contribution to total retail sales, but then the prediction jumps to 13 billion US Dollars or $8 \%$ of total retail sales. This increment is due to better data availability and the extreme growth of user numbers in e-commerce platforms all over Indonesia (Syarizka, 2019). Based on this data, it can be concluded that $92 \%$ of the retail purchases in Indonesia are still made offline rather than online.

Furthermore, United Nations Conference on Trade and Development (UNCTAD) reveals Indonesia B2C e-commerce index is ranked 84 out of 152 countries and are considerably low (Sindo, 2019). Meanwhile, databoks (2020) shows the number of e-commerce users in Indonesia in 2017 were 139 million (51\% from 261.89 million population), increased to 154.1 million (58\% from 263.94 million population) in 2018 and 168.3 million (63\% from 267 million population in 2019. This indicate that e-commerce still has great opportunity in Indonesia. Thus, e-commerce is required to develop strategies to increase customers' purchase intention and purchase decision. In order to develop the strategies, analyzing the factors influencing purchase intention in affecting purchase decision of e-commerce customers is important.

The Ministry of National Development Planning of Indonesia, Bambang P.S. Brojonegoro said that the e-commerce transaction in Indonesia is mostly in Greater Jakarta. Seventy percent of e-commerce customers live in Greater Jakarta (Putra, 2019). Meanwhile, kompas.com mentioned that $80 \%$ of e-commerce consumers are young people and woman (kompas.com, 2019). This data are supported by detiknet (2019), which is showed that people born between the year 1980 to 2000 are the most internetpenetration age range in Indonesia. They are now in the age of 19-39 years old.

These phenomena bring out a question on what drives the customer's purchase intention in affecting purchase decision of e-commerce customers in Greater Jakarta, especially people born between the year 1980 and the year 2000 .

This research addresses 5 questions, which are: 1 ) Does purchase intention has an effect on purchase decision? 2) Does perceived risk influence purchase intention? 3) Does perceived benefit influence purchase intention? 4) Does trust influence purchase intention? And 5) Does brand image influence purchase intention? By answering those questions, the researcher expects to find out how significant perceived risk, perceived benefit, trust, and brand image are affecting purchase intention and then the significance of purchase intention toward purchase decisions of e-commerce customers in Greater Jakarta born between the year 1980 and year 2000 .

This research is expected to contribute to two benefits. First, the result of this research could be used by e-commerce companies in developing their strategies to increase the online consumers' purchase intention 
and purchase decision, especially for customers aged between 19 and 39 who live in Greater Jakarta. Second, this research provides a more in-depth insight into theoretical com-prehension and knowledge on the effect of customer purchase intention toward purchase decisions. It also shows the influence of perceived risk, perceived benefit, trust, and brand image on purchase intention.

This research focuses on how does purchase intention influence purchase decisions, and factors affecting purchase intention, such as perceived risks, perceived benefit, trust, and brand image. This research studies active online buyers born between the year 1980 and 2000 who currently live at Greater Jakarta..

\section{Perceived Risk}

Barnes (2007) explained perceived risk according to Dowling and Staelin (1994) means a consumer's perception of uncertainty when they purchase a product where it leads to doubt in purchasing and asking the consequences if they proceed to purchase. The consumers will be uneasy about the pre-purchase experience worrying for unexpected losses due to the purchase of a product (Tanadi, Samadi, \& Gharleghi, 2015). Perceived risk means a consumer's doubt regarding the aftermath of their decision, and it is an important factor that influences purchase decisions (Nguyen \& Gizaw, 2014). Garbarino and Strahilevitz (2004) mention perceived risk as to the effect of perception of the probability that something might be wrong and perception of how fatal is the consequences (Mazhar, Jam, \& Anwar, 2012). While according to Pries (2004) perceived risk is a feeling of doubt felt by consumers that the product they bought might not function as it is supposed to do (Khairunnisa et al., 2018). Perceived risk as said by Hoover et al. (1978) exists when the result of the purchase can't be predicted, and nothing is certain, and by Engel, Blackwell, and Miniard (1995) it rather means the unexpected result related to a product or service (Wang \& Tsai, 2014). In conclusion, perceived risk in this research paper means the risk felt by potential customers pre-purchase as there are uncertainty and the unknown result of the purchase.

There are seven types of risks, according to Jacoby and Kaplan (1972), they are financial risk, performance risk, psychological risk, physical risk, social risk, time risk, and opportunity cost risk. While in the case of online shopping and transaction, three types of risk are dominant, according to Bhatnagar, Misra, and Rao (2000). The three dominant risks consist of financial risk, product risk, and information risk in which information risk involves security and privacy (Rachbini, 2018). Risks correlated with online purchase intention are delivery risk, privacy risk, quality risk, and time risk (Tanadi et al., 2015). Different types of risks are explained by Nguyen and Gizaw as financial risk, functional risk, physical risk, and social risk. Financial risk is the financial loss suffered from the purchase decision. Functional risk represents that a product will not meet its function as expected, physical risk implies that a product will be hazardous for health and social risk is risks involved with the consumer's status and image (Nguyen \& Gizaw, 2014).

Based on the previous explanation, there are many dimensions of perceived risk and they vary among researchers. Some dimensions are the same and some are different. After identifying the explanation of each dimension, they could be classified into six dimensions. The six dimensions are financial risk, performance risk (included product risk, quality risk, and functional risk), time risk, psychological risk (included privacy risk and social risk), source risk (included physical risk and opportunity cost risk), and delivery risk (included security risk). Those six dimensions have covered all the dimensions which were used by previous researchers. These six dimensions are used in this research.

Financial risk as explained by Ibrahim, Suki, \& Harun (2014) is the risk in financial perspectives such as credit card information and costs. Performance risk is the thoughts that the product or service they purchase will have a gap between expectations from reality. While time risk is the risk that the process of purchase will consume a lot of time (Khairunnisa et al., 2018). Psychological risk, according to Lim (2003) means the risk associated with mental stress caused by the purchase. Cases (2003) and Lim (2003) also mentioned source risk, which is the risk where there are chances for consumers to purchase from unreliable businesses (Ibrahim et al., 2014). Meanwhile, the delivery risk is the risks associated with the delivery process as the product may not be delivered well (Tanadi et al., 2015).

\section{Perceived Benefit}

Chen and Dubinsky (2003) explained perceived benefit as a reward expected by consumers (Koohikamali, Mousavizadeh, \& Peak, 2019). Kim, Ferrin, and Rao (2007) defined perceived benefit as to how far consumers believe that they will be better by doing an online transaction with a specific website (Rachbini, 2018). Forsythe, Liu, Shannon, and Gardner (2006) described perceived benefit as what consumers will get in return of doing shopping online, while Kim et al. (2008) described it as how consumers think that a certain online transaction is better when it is compared with another online transaction. $\mathrm{Wu}(2003)$ mentioned the perceived benefit in their research as the total benefit that satisfies consumer's needs and wants (Tanadi et al., 2015).

Zhang, Long, Xu, Tan (2013), and Bhatnagar and Ghose (2004) proposed that in the context of online shopping, perceived benefits are basically researched on a utilitarian and hedonic base. Utilitarian benefit, according to Chaabane and Volle (2010) is related with functional and cognitive means that lead to consumer value while in accordance with the statement of Hirschman and Holbrook (1982), the hedonic benefit is regarded as an experiential and emotional benefit (Sozer \& Civelek, 2018). Khairunnisa, Hafidhuddin, 
and Tanjung defined perceived benefit with comparison to an offline store. According to them, perceived benefit is the perception made by consumers on the benefit and convenience offered by e-commerce in comparison with brick and mortar stores (Khairunnisa et al., 2018).

In conclusion, the perceived benefit in this research refers to the benefit felt by potential customers or customers due to the purchasing process and result. Perceived benefit is measured through shopping convenience, product selection, and shopping flexibility (Sozer \& Civelek, 2018).

Shopping convenience is the ability to shop without being limited by time and place, where the customers will be able to purchase anywhere on anytime, within a short period of time, and simple shopping process (Tanadi et al., 2015). Product selection, explained by Dillon and Rief (2004) is the depth and width of products and the information available to support consumers in making a decision. Product selection provides the chance to compare, contrast, and select products or service among many options. Furthermore, Chabal (2013) described the ease of shopping or shopping flexibility to be the level of ease or efficiency to shop. Zaidi, Gondal, and Yasmin described the ease of shopping as the awareness of consumers in utilizing technology to decrease the effort and make shopping easier (Tanadi et al., 2015). Shopping flexibility is also incorporated with perceived benefit as it means the flexibility of shopping online without time constraint, and to choose when to complete the transaction (Sozer \& Civelek, 2018).

\section{Trust}

Whinston Zhang (2003), Beatty, Mayer, Coleman, Reynolds, and Lee (1996), Urban, Sultan, Qualls (2000), and McKnight and Chervany (2002) agrees that trust is a subjective belief, where an individual is consciously willing to be vulnerable and rely on others (Rachbini, 2018). Mayer, Davis, and Schoorman (1995) argue that trust is the tendency where an individual with their own will, accept the attitude of another individual although the first individual doesn't have control over the second one and is not protected by the second individual (Puspitasari et al., 2018). The concept of trust by Alamsyah, Trijumansyah, and Hariyanto (2017) can mean an expectation of consumers toward a store, people, and or products that they will fulfill their promise, be reliable, and dependable (Gunawan et al., 2019). E-trust is defined by Gefen (2002) that it is an attitude, a consumer's own perception of belief while making transactions online from an online retailer (Jonsson et al., 2019).

In an online transaction, McCard (2002) defined trust as the willingness of the consumer to accept the disadvantages of online transactions because they have positive expectations for the online store behavior in the future (Rafsandjani, 2018). Rotter (1971) defined e-interpersonal trust. It is an expectation held by an entity that words, promises, verbal and written statements of another entity is reliable (Zamrudi et al., 2016).

In conclusion, trust refers to the behavior of a consumer where he or she is willing to rely upon and believe in the product or services, and promises or information made by an online retailer. In this research, trust is measured through four key dimensions which are integrity, competency, consistency, and transparency (Robbins \& Judge, 2007). Those four dimensions have covered the trustworthiness in e-commerce transaction. Those are honesty and truthfulness, competency in knowledge and technical skill, reliability, and excellent promotion and services.

\section{Brand Image}

Brand image has been defined by Peter and Olson (2000) as the consumer's perception and preference of a brand, and it is reflected by associations of variables of the brand that are memorized by the consumer (Arif, 2019). Cannon, Perreault, and McCarthy (2009) explained brand image to be opinion and consumer's confidence in the product quality created by an organization and that the organization is honest in the products they offer to consumers. But further back, Keller (1993) defined brand image as the perception of product reflected in the memory of a consumer due to their subjective reasons and own personal emotions. This is pretty similar to Malhotra (2010) that refers to brand image as the consumer perception of either logical or reasonable basis through emotions toward a brand. Pujadi (2010) explained the brand image in a psychological term that the image of a brand is subconsciously planted to the consumer's mind through experiences and expectations..

Foster (2018) describe the brand image as anything associated with the brand and how much a consumer is confident about a particular brand. It is, according to Zhang (2015), the understanding of a consumer to a brand is based on any brand-related events held by the firm. Ilham (2018) explained that it is a reasoned or emotional perception of how much a consumer is affected by a brand (Gunawan et al., 2019). Keller, Prameswaran, and Jacob (2011) argue that brand image is the subjective perception toward a brand crafted in one's memory because of involvement with a certain brand (Arslan \& Zaman, 2014). Furthermore, Ferrell and Hartline (2011) described the brand image as a total final impression of a brand, whether it is positive or negative that consumer keeps in their mind. This involves everything that has been done by the company in the past, what they are currently doing and offers, and the forecast of what they will do in the future (Zamrudi et al., 2016).

In conclusion, brand image is the perception a consumer has in their mind regarding a brand that results from past experience and expectations. According to Zamrudi, et al., (2016), brand image is measured through five dimensions, which are brand identity, brand personality, brand association, brand attitude and behavior, and brand benefit and competence. These dimensions have covered the practical function, positive symbolic meaning, pleasant experience, 
consumers' good perception, and e-commerce attributes.

\section{Purchase Intention}

The theory of planned behavior is used to understand behavior and predict it. It is determined by behavioral intention., which is affected by attitudes toward the behavior, subjective norms, and perceived behavioral control (Kan \& Fabrigar, 2017). The theory of planned behavior has been used successfully to predict and explain a shopping behavior. A planned behavior where customers are willing to buy a product is known as purchase intention (Ajzen, 2992 in (Nguyen \& Gizaw, 2014).

Eagly and Chaiken (1993) argued that intention is an individual's motivation to consciously plan to do an action or behavior (Jonsson et al., 2019). Intention to buy defined by Talha (2006), relates to the state of mind reflecting the plan of a buyer to purchase a certain brand within a certain period (Rafsandjani, 2018). Online purchase intention is explained by Pavlou (2003) as the situation when customers are willing and have the intention to be involved in a transaction online. While the online transaction is the activity with processes such as retrieving information, transferring information and purchasing the product (Rafsandjani, 2018). Kotler (2006) defined purchase intention to be consumer's behavior when they are interested in purchasing a product or service (Khairunnisa et al., 2018).

Paramita and Yasa (2015) explained that purchase intention is the mental activity preceding the action of a person before using a product or service (Puspitasari et al., 2018). Purchase intention is also studied by Zaman and Arslan, in which they defined it as the possibility of a consumer to purchase a product or service, a positive purchase intention is when the actual purchase happens and vice versa, negative purchase intention is when the actual purchase didn't happen (Arslan \& Zaman, 2014). Quite recently, Zamrudi, Suyadi, and Abdillah also did research on purchase intention, and according to them, purchase intention is collected from all learning and thinking process that causes perceived feeling toward a certain product (Zamrudi et al., 2016).

In conclusion, this research defines purchase intention as a subject's motivation and intention to have a conscious plan or consideration to expectedly, willingly, and likely perform a purchase. Ferdinand (2006) stated that purchase intention could be measured through indicators like transactional interest, referential interest, preference interest, and exploratory interest. Transactional interest is the tendency of a consumer to purchase a product. Referential interest, is the tendency to refer/recommend the product to other people. Preference interest is where a person will have a primary preference for a certain product. And exploratory interest is when a person continuously search for information related to a product to support the positive characteristic of the product (Rafsandjani, 2018). While Ajzen (2010) stated that intention includes several concepts such as expectations, likelihood, and willingness. Intention to purchase can mean a person's intention to perform an act of purchasing or expects to make a purchase (Jonsson et al., 2019).

\section{Purchase Decision}

Salem (2018) explained that purchase decision is the process where customers are encouraged to identify needs, create options, and to select specific brands or products. It means a series of choices before the purchase happens. This could come in the shape of where to purchase certain products, what brands or models to buy, when to buy, how much should the customers spend, what payment method to use, etc. (Gunawan et al.,, 2019). A similar definition is stated by Lovelock and Wirtz (2007). They described purchase decision as the purchasing process, in which customer will have an experience to select, take, and perceive a service through three steps which are pre-purchase stage, encounter of service stage, and post encounter stage (Nugraha et al., 2018). Purchase decision according to Kotler and Levy (1969) is the behavior shown by the decision-maker as they buy, use or dispose of goods and services, while David and Albert (2002) argued that purchase decision is a long process in which customers evaluate, acquire, use or dispose of goods or services (Khuong \& Duyen, 2016). In conclusion, purchase decision in this research means the process of selecting, taking, and perceiving a product or service, in which the consumer will search for information regarding the product, evaluate it before making the purchase, decide to do the purchase and feel satisfaction or dissatisfaction for the purchase.

There are three stages in the purchase decision (Nugraha et al., 2018). The first stage is the pre-purchase stage, which takes place before the purchase happens. At this stage, the customers will observe and calculate the product or service offered to make the purchase decision. The second stage is the encounter of the service stage. Here, customers will have contact and interact with the service provider. There are two kinds of contact services which are high and low. High contact service is when customers and service providers meet, usually face to face, to make the purchase, while low contact service is when customers and service providers usually communicate through media such as website, phone, email, etc. The last stage is post-encounter stage, this is where the purchase is made, they have experienced the purchase and evaluate their satisfaction towards the service based on their expectations and perceptions.

Kotler and Armstrong (2001), described decision making as a process of solving problems that contain five stages. The stages are problem recognition, the search of information, alternatives evaluation, purchase decision, and the behavior after purchase (Puspitasari et al., 2018). Davis and Bagozzi (1989) revealed that several types of research in human behavior has developed models such as the Theory of Planned Behavior and the Technology Acceptance 
Model, those models have shown that there is an assumption that intention or interest preceded behavior and thus, purchase intention influences purchase decision (Puspitasari et al., 2018). The intention, according to Ajzen (2005), is characterized as the antecedent of behavior, this means intention is the actual effort to do a certain behavior like purchase (Jonsson et al., 2019). In the e-commerce study, Pavlou and Fygenson (2006) found that many researches of e-commerce have similar findings that consumer's intention to do online transaction is a significant factor in predicting their actual purchase (Rachbini, 2018).

\section{Theoretical Framework}

In accordance with the literature review presented below, this research has developed a theoretical framework as shown on Figure 3. It shows how the perceived risk, perceived benefit, trust, and brand image influence purchase intention and how purchase intention influences purchase decision of e-commerce customers in Greater Jakarta

Based on the theoritical framework above, it can be formulated some hypotheses as follow:

\section{Hypothesis $1\left(\mathrm{H}_{1}\right)$ : \\ Perceived risk influences purchase intention}

Kim, Ferrin, and Rao (2007) argue that perceived risk is one of the biggest barriers for consumers who want to make an online purchase or consider making online purchases as they believe there are potential negative outcomes and uncertainty in online transactions. It is very usual for consumers to feel reluctant to purchase online as the risk in online shopping is overwhelmingly larger than offline shopping. The impact of perceived risk toward purchase intention is negative; the less the perceived risk is, the more probable that the consumer will make online purchases (Rachbini, 2018). Bhatnagar, Misra, and Rao (2000) also agree that perceived risk has a negative impact on purchase intention in both product and services. While information risk and product risk strongly influences perceived risk, risk of security in payment and personal data is greatest threat that influences purchase intention through internet media. This means that the relationship between perceived risk and purchase intention is negative, yet very significant (Khairunnisa et al., 2018). Naiyi (2004) stated that the growth of the internet has made consumers more concerned about

Figure 3. Theoritical Framework

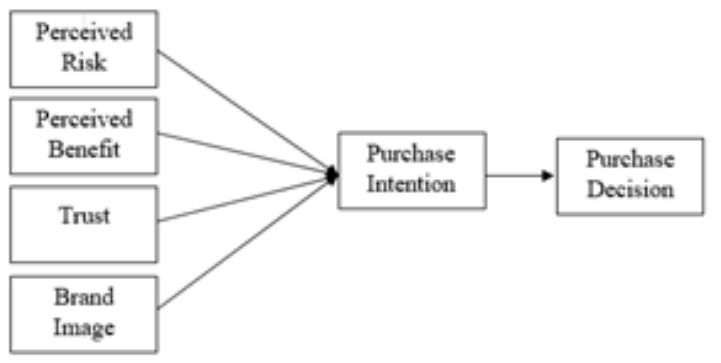

their purchase decision as they will definitely think of the risk involved. Thus it is the most significant factor that affect purchase intention (Tanadi et al., 2015). But on the other hand, a study done on Lazada in 2018, shows that risk perception and intention of online purchase has not been significantly related as risk didn't impact online purchase intention (Puspitasari et al., 2018).

\section{Hypothesis $2\left(\mathrm{H}_{2}\right)$}

Perceived benefit influences purchase intention

Margherio (1998) found that consumers who purchase online, choose the online mode because they experience many benefits rather than shopping offline. Kim, Ferrin, and Rao (2007) stated that opposite to perceived risk, perceived benefit is one of the greatest causes of online purchase intention. The relationship between perceived benefit and purchase intention is positive and highly significant (Rachbini, 2018). Ciptaningsih (2011) made a statement that the low online purchase amongst high internet user in Indonesia is due to the consumers haven't experience the benefit, comfort, and usefulness online transaction offers. This is supportive to Davis (1989), who says that in online shopping when consumers felt the benefit, they will have a higher purchase intention. For many people, they preferred online shopping because of the benefit provided, and thus perceived benefit strongly influences purchase intention (Khairunnisa et al., 2018). In Y-Generation, the online purchase intention is experiencing an increase, and this is due to the perceived benefit being greater than the perceived risk, internet shopping benefit is significantly related with intention to shop online (Tanadi et al., 2015).

\section{Hypothesis $3\left(\mathrm{H}_{3}\right)$ \\ Trust influences purchase intention}

Several researchers who have done research on trust are studied by Bhattacherjee (2002), it is shown that many of them have proved the relationship between trust and purchase intention in the context of online shopping. Trust is a really crucial factor in online purchase intention as consumers will have a higher probability of being engaged in an online transaction when trust is high (Rachbini, 2018). E-trust, according to Das (2016), has taken a major contribution to the e-retailer industry because the primary consequence of e-trust would be purchase intention (Jonsson et al., 2019). But, the research done by Jonsson et al. (2019) later found out that their hypothesis of e-trust affecting purchase intention is rejected. Hu, Ding, Li, Cheng, and Yang (2019), on the other hand, suggest that there should be a sufficient amount of trust in the fin-tech industry because the impact is really enormous (Meyliana, Fernando, \& Surjandy, 2019). Research has been done to find out the purchase intention in Lazada e-commerce, and the result shows that trust is the most affecting and positive factor with the greatest result in SEM processing (Puspitasari et al., 2018). This argument is also supportive of Zamrudi, Suyadi, and Abdillah's research, where they found out 
trust is significant and has a strong effect on purchase intention (Zamrudi et al., 2016).

\section{Hypothesis 4 ( $\left.\mathrm{H}_{4}\right)$ \\ Brand image influences purchase intention}

Brand image has a positive and yet significant effect on purchase intention. Jalilvand (2012) also found that brand image has decisive role in purchase intention (Torlak, Ozkara, Tiltay, Cengiz, \& Dulger, 2014). A consumer will have a higher preference to purchase from brands with a good image, an increment in the brand image will cause enhancement in the purchase intention. Graeff (1997) mentioned that in tight competition, brand image plays an important role compared to the physical characteristic of the brand. Ekinci and Hosany (2006), Kleijnen, Ruyter, and Andreassen (2015) and Nguyen and Leblanc (2001) argued that creating an image is essential to attract and retain consumers (Arslan \& Zaman, 2014). Brand should be treated like a human being with attitude, people will appraise the attitude through outcomes such as purchase intention. Arista (2011) and Prabowo (2014) also agreed that brand image has a strong and significant impact on purchase intention (Zamrudi et al., 2016).

\section{Hypothesis $5\left(\mathrm{H}_{5}\right)$ \\ Purchase intention influences purchase decision}

Pavlou and Fygenson (2006) found that there have been many studies in the e-commerce industry that show how consumer intention to be engaged in transactions online will be a significant predictor of the consumer's actual participation in the online transaction. Ajzen and Fishbein (1980) also found that the relationship between intention and behavior is basically based on the assumption that mankind tried to have a rational decision by calculating available information. Hence, a person's behavioral intention and decision to do or not do behavior is the direct and immediate determinant of the person's actual behavior. In the case of purchase intention, Kim, Ferrin, and Rao (2007) found that purchase intention is a strong predictor to purchase decision (Rachbini, 2018). Purchase intention is said by Keller (2001) to be connected to a consumer's behavior, perception, and attitude. When a person decides to purchase something from a store, it is because they are driven by intention (Jonsson et al., 2019). Kinnear and Taylor (1995) found that a study done by Esthi Dwityanti shows purchasing interest is the stage where the respondents have a tendency to act, just before the decision to purchase is created (Rafsandjani, 2018). A study has also been done in Vietnam towards the C-Generation buying intention on Korean products. The result proves that behavioral intention is a strong driver of purchase decisions (Truong, 2018). This is consistent with Takhire and Joorshari's (2015) research that says purchase intention significantly influences purchase decisions. A case was also studied for Lazada e-commerce, and the result shows a positive and significant influence of online purchase intention toward the actual decision of the online purchase (Puspitasari et al., 2018).

\section{RESEARCH METHOD}

This research employs quantitative method to measure each variable studied. The population of this research is e-commerce customers living at Greater Jakarta aged between 19 and 39 years old. The reasons are e-commerce transactions in Indonesia are mostly in Greater Jakara (Putra, 2019) and 80\% of e-commerce customers are young people and woman (kompas.com, 2019).

The questionnaire was distributed to 300 samples (respondents) and selected by purposive snowballing sampling method. It is a method in which one participant will encourage other potential participants to take part in the study.

A questionnaire was developed to measure all variables: perceived risks (PR), perceived benefits (PB), trust (T), and brand image (BI), purchase intention (PI) and purchase decision (PD). Each variable is measured by some indicators/statements using the interval scale, from 1 (strongly disagree) to 7 (strongly agree).

Perceived risks (PR) are measured through financial risk, performance risk, time risk, psychological risk, and time risk by adjusting a questionnaire made by Ibrahim et al. (2014) and adding adjusted questionnaire by Javadi et al. (2012) to measure delivery risk. In the questionnaire, PR is measured by 13 indicators.

For perceived benefits (PB), it is measured through shopping convenience, pro-duct selection, shopping flexibility, and shop-ping enjoyment. Shopping enjoyment, product selection, and shopping flexibility adjust questionnaire by Sozer \& Civelek (2018) while shopping enjoyment adjusts questionnaire from Khairunnisa et al. (2018). In this research, PB is measured by eight indicators.

Trust (T) is measured by using two questionnaires from previous researches, which are Zamrudi et al. (2017) and Che, Cheung, \& Thadani (2017). To measure brand image, adjusted questionnaires from Rahi et al. (2020) and Suhaily \& Darmoyo (2017). There are 5 indicators are used to measure T (trust).

Purchase intention is measured through adjusted questionnaires made by Che et al. (2017) and Nugraha et al. (2018). There are five indicators also used to measure PI (purchase intention).

Last but not least, to measure purchase decision (PD), the researcher use questionnaires made by Nugraha et al. (2018) and Fadlurrohman (2018) with adjustment to suit the purpose and target of this research. There are four indicators are used to measure PD.

The questionnaire was developed with English as the main language, however as the population is e-commerce customers aged between 19 and 39 from Greater Jakarta, Bahasa Indonesia was added as the description for each question to help the samples better understand the question. 
The questionnaire was made by using Google Form and it is spread through social media, mainly Line, WhatsApp, Instagram stories, and direct messages. The data gathered was exported into Microsoft Excel documents to be analyzed with statistical software to measure the validity, reliability, and to test the hypotheses. To verify that respondents of this research are eligible to answer the questionnaire, the respondents have to answer through a few screening questions so that only respondents who fulfill the criteria of research can proceed to fill the questionnaire.

The data were processed and analysed by using Structural Equation Model (SEM) Analysis, to examine the influence of perceived risk, perceived benefit, trust, and brand image to purchase intention and the influence of purchase intention to purchase decision.

\section{RESULT AND DISCUSSION}

This research involved 300 respondents, mostly aged between $19-25$ years old. It amounts to 225 people or $75 \%$ of the total respondents. The respondents aged between 26 - 32 years old amount to 42 people, which is $14 \%$ of the total respondents. The percentage is followed closely by respondents aging between 33 - 39 years old at $11 \%$ (33 people).

Most of the respondents to this research purchase from e-commerce at a frequency of less than onceper-month. With a total of 300 respondents, 143 people $(47.7 \%)$ shopped less than once a month, 80 people $(46.7 \%)$ shopped once a month, and 77 people (25.6\%) shopped more than once-per-month.

The respondents of this research mostly (118 out of 300) prefer Shopee as their e-commerce platform. The second favorite e-commerce is Tokopedia, with 62 respondents $(20.7 \%)$ agreeing that Tokopedia is their favorite platform. As for the next favorite e-commerce, are followed by JD.id (10\%), Traveloka (5.6\%), Lazada (5\%), Zalora (4.3\%), OLX $(3.3 \%)$, Berrybenka $(2.3 \%)$, and $9.5 \%$ prefer other e-commerces

All variables used in this research are valid based on the result of Kaiser-Meyer-Olkin (KMO) of Sampling Adequacy and Bartlett's test. The KMO of Sampling Adequacy showed the result of 0.925 in the test, which is above 0.6 as the minimum value to be valid. The Bartlett's significance in this research has a value of 0.000 , which is less than 0.05 as maximum value for validity.

All variables studied in this research were measured reliably with the measurements. The minimum value of Cronbach's Alpha should exceed 0.6 to be considered as reliable. In this research, perceived risk's Cronbach's Alpha has passed with a the value of 0.960 , perceived benefit of 0.869 , trust of 0.894 , the brand image of 0.859 , purchase intention of 0.836 , and purchase decision with a score of 0.837 .

\section{Model Test}

There are some criterias to determine whether the model is fit or not. Table 1 shows the summary output of the goodness of fit test of this research.

The model fit of this research is determined by several parameters such as CMIN/DF (Chisquare/Dedgree of Freedom), GFI (Goodness of Fit Index), AGFI (Adjusted Goodness of Fit Index), TLI (Tucker Lewis Index), CFI (Comparative Fit Index), and RMSEA (Root Mean Square Error of Approxi-mation).

The result of SEM analyis shows that the value of CMIN/DF is 1.545. The GFI and AGFI have a score of 0.859 and 0.824 consecutively. For TLI and CFI, the scores are 0.961 and 0.960 , and the RMSEA score is 0.043 . To be considered that the model is fit or not, the CMIN/DF should be between 1.5 to 2, GFI, AGFI, TLI, and CFI above 0.9, and RMSEA below 0.08. The CMIN/DF, TLI, CFI, and RMSEA have passed the requirements. Hence, it can be concluded that the model is fit because it passed at least four of the measurements.

\section{Hypothesis Testing}

Figure 4 shows the hypothesis path diagram based on SEM analysis. Each variable was measured by some indicators as follows:

(1)Variable PR (perceived risk) was measured by 13 indicators, (2)Variable PB (perceived benefit) was measured by 8 indicators, (3)Variable T (trust) was measured by 5 indicators, (4)Variable BI (brand image) was measured by 5 indicators, (5)Variable PI

Table 1. Summary of Goodness of Fit Test

\begin{tabular}{|c|l|c|c|c|}
\hline No. & Goodness of Fit Indicators & $\begin{array}{c}\text { Suggested } \\
\text { Value }\end{array}$ & Result & Evaluation \\
\hline 1. & CMINDF & $\leq 5.000$ & 1.545 & Good \\
\hline 2. & GFI (Goodness of Fit Index) & $\geq 0.900$ & 0.859 & Good enough \\
\hline 3. & $\begin{array}{l}\text { AGFI (Adjusted Goodness of } \\
\text { Fit Index) }\end{array}$ & $\geq 0.900$ & 0.824 & Good enough \\
\hline 4. & CFI (Comparative Fit Index) & $\geq 0.900$ & 0.960 & Good \\
\hline 5. & TLI (Tucker Lewis Index) & $\geq 0.900$ & 0.961 & Good \\
\hline 6. & $\begin{array}{l}\text { RMSEA (Root Mean Square } \\
\text { Error of Approximation) }\end{array}$ & $<0.080$ & 0.043 & Good \\
\hline
\end{tabular}

(purchase intention) was measured by 5 indicators, (6)Variable PD (purchased decision) was measured by 4 indicators

Table 2 shows that perceived risk (PR) toward purchase intention (PI) has a P-value of 0.007 and estimate value of -0.048 . Since the P-value is below 0.05 , it can be concluded that perceived risk has a significant influence on the purchase intention of e-commerce customers in Greater Jakarta. So, the hypothesis 1 is accepted. The negative value of -0.048 means that perceived risk has negative influence to purchase intention. It means that the higher the perceived risk the lower the purchase intention of e-commerce customers in Greater Jakarta.

For the regression weight of perceived benefit (PB) to purchase intention (PI), it is shown that the 
$\mathrm{P}$-value is ***, it means the $\mathrm{P}$-values is below 0.001 , with a positive value estimate $(0.282)$. This result indicates that the influence of perceived benefit is positive significant towards purchase intention. When the perceived benefit increases, the purchase intention will also effectively increase. Therefore, the hypothesis 2 is accepted.

Moving to the regression weight of trust $(\mathrm{T})$ to purchase intention (PI), the tables show P-value below 0.001 and the estimate value of 0.282 . The result represents a significant and positive influence of trust on purchase intention. As the customers gain more trust, it will strongly increase the purchase intention, and vice versa, the purchase intention will decrease when the customers lack trust. That is why the hypothesis 3 is also accepted.

Next, the table 2 shows the regression weight of brand image (BI) toward the purchase intention (PI). The P-value of brand image (BI) is below 0.001, and the estimate value is 0.368 . Since the P-value is below 0.05 , it indicates that brand image has significant influence to purchase intention. When an e-commerce

Figure 4. Hypothesis Path Diagram

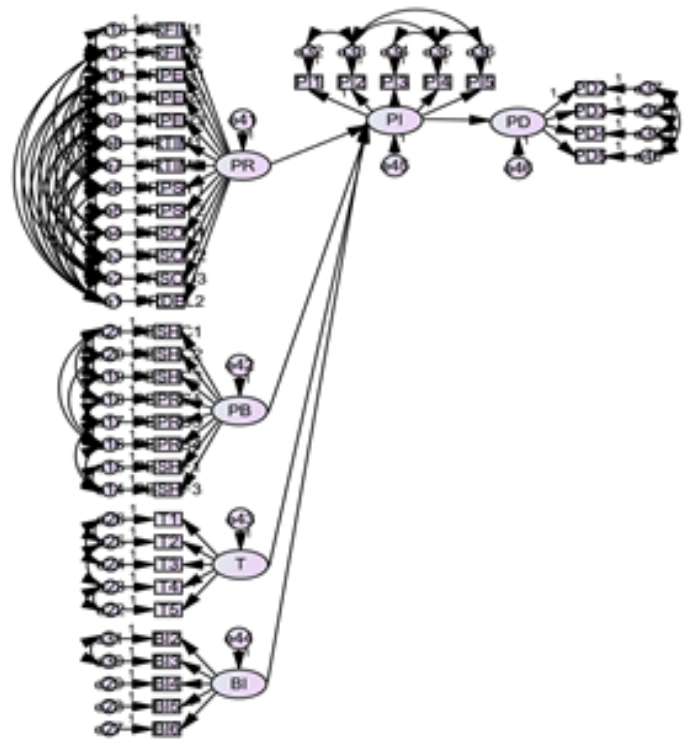

company has a good brand image in their consumers' mind, it will push the purchase intention to a significant increment. It means that the hypothesis 4 is accepted also.

Last but not least, the table 1 also shows the regression weight of purchase intention (PI) toward the purchase decision (PD). The P-value shown is below 0.001 , and the estimate value is 0.612 . Since the $\mathrm{P}$-value is below 0.05 , a conclusion can be drawn that purchase intention has significant influence to purchase decision. Furthermore, the estimate value of PI is 0.612 means that purchase intention is having significat influence on purchase decisions in a positive manner. As the purchase intention of e-commerce customers in Greater Jakarta increases, the purchase decision will grow stronger too. Therefore the hypothesis 5 is accepted.

\section{Discussion}

The hypothesis 1 (H1) is accepted. The perceived Table 2. Regression Weight

\begin{tabular}{clllll}
\hline Hypo-thesis & Relati-onship & $\begin{array}{c}\text { Standar-dized } \\
\text { Coeff-icient }\end{array}$ & S.E. & P & $\begin{array}{c}\text { Support of } \\
\text { Hypo-thesis }\end{array}$ \\
\hline 1 & PR $\rightarrow$ PI & -.048 & .018 & .007 & Accepted \\
2 & PB $\rightarrow$ PI & .282 & .076 & $* * *$ & Accepted \\
3 & T $\rightarrow$ PI & .234 & .055 & $* * *$ & Accepted \\
4 & BI $\rightarrow$ PI & .368 & .073 & $* * *$ & Accepted \\
5 & PI $\rightarrow$ PD & .612 & .106 & $* * *$ & Accepted \\
\hline
\end{tabular}

risk has a negative significant influence to purchase intention of e-commerce customers. This result is in line with some pieces of research done by Rachbini (2018), Khairunnisa et al. (2018), and Tanadi et al. (2015) which states the negative impact of perceived risk toward purchase intention of online shopping. This might be due to the behavior of the customers before they perform the purchase. Millenials, in Indonesia Millennial Report 2019 as a report done by IDN Times has found that millennials will have a lot of information gathering and consideration to do before they purchase, and hence will feel secure about their purchase. Furthermore, having a bad experience in online shopping will stop them from the online shopping activity, but rather stop shopping from stores that caused the bad experience (Wicaksono, 2019). Christin Djuarto, the Director of Shopee Indonesia also mentioned that customers tend to search for information such as warrant, seller image, and review as an important aspect before they purchase online (Tashandra, 2018).

The hypothesis $2(\mathrm{H} 2)$, which is perceived benefit influences purchase intention, is also accepted in this research. Perceived benefit positively and significantly influences purchase intention. This finding is in terms of the findings of Khairunnisa et al. (2018), who found the positive and significant influence of perceived benefit towards online purchase intention of Islamic fashion in Indonesia. It is also in accordance with Rachbini (2018) that found the significance of perceived benefit toward the purchase intention of e-commerce customers in Indonesia. Furthermore, it is also in line with the findings of Tanadi et al. (2015) in which perceived benefit would positive and significantly influence the online purchase intention of Gen-Y in Malaysia. This means that it is very important for e-commmerce companies to offer more benefit to their customers, as it can have a significant impact on their intention to purchase.

The hypothesis $3(\mathrm{H} 3)$ in this research is also accepted. The test has shown a positive and significant influence of trust to purchase intention. This result is similar to research done by Puspitasari et al. (2018), in which they have found that trust is the most affecting factor of purchase intention in e-commerce. It also supports the findings of Meyliana et al. (2019) that trust significantly influences the intention in the FinTech industry. It is also agree with Rachbini (2018), 
and Zamrudi et al. (2017) that state the significance of trust toward purchase intention. Thus, it is in contradiction with the findings of Jonsson et al. (2019) that prove trust doesn't make a significant effect on the purchase intention of e-retailer customers. In some cases, especially for product with strong brand image, the effect of trust on purchase intention could not be significant. For some reasons, a strong brand image is a guarantee that customer can rely on. It is important to note this finding, that even in some cases trust does not significant influence purchase intention, e-commerce should set a strategy to create and maintain their customer's trust.

The hypothesis $4(\mathrm{H} 4)$ mentions the influence of brand image towards purchase intention. The test result has shown that brand image indeed significantly influences purchase intention in a positive manner. This finding is in terms of the research by Torlak et al. (2014), who have found that brand image significantly influences purchase intention of young cell-phone customers in Turkey. It is also supported by Arslan \& Zaman (2014) in the retail industry, where they prove the significance of brand image towards purchase intention. With this finding, e-commerce companies must be able to set a good brand image in the customer's mindset, since the brand image can significantly affect their purchase intention.

The hypothesis 5 (H5) of this research is accepted. It is supported that purchase intention has a positive and significant influence on the purchase decision. This is in line with previous researches done by Rachbini (2018), and Puspitasari et al. (2018), which stated the significant influence of purchase intention toward purchase decisions in the e-commerce industry at Indonesia. Furthermore, it also supports previous research of Truong (2018) that concludes the significance of purchase intention toward the purchase decision of Korean products for generation $\mathrm{C}$ in Vietnam.

\section{CONCLUSION}

In the perspective of perceived benefit, the respondents of this research mostly agrees that large product range and availability of many brands and stores are benefits they experienced the most in online shopping. Therefore, it is recommended for e-commerce companies to broaden their product and service availability, and to cooperate with more brands and stores so that they can channel their products through e-commerce. For trust, respondents agree that they trust information posted on e-commerce sites to be true. It is recommended that e-commerce companies can provide true information and to make sure that the information posted by sellers and brands are reliable. The respondent agreed that they think their e-commerce have a brand image that is liked by consumers. Hence, it is notable for e-commerces to be consumer-friendly.

For e-commerce companies, with all the hypotheses answered, it is important to note that once the customer has the intention to purchase, it is likely that the intention will turn into a purchase decision. This means it is very important to increase the customer's purchase intention. Increment of purchase intention can be done by making the customers feel benefited, especially in terms of shopping convenience, product selection, and shopping flexibility and by increasing customer trust and building a better brand image.

This research studies the influence of perceived risk, perceived benefit, trust, and brand image toward purchase intention and the influence of purchase intention towards purchase decision of e-commerce customers in Greater Jakarta. In the future, researchers may study this subject in different area or in Indonesia as a country, since different area with different internet penetration and level of development might have a different result.

Although the result might or might not be applicable to different industries, areas, locations, and subjects, it might be used as a reference for further studies. This research is also limited by several factors such as time, number and area of respondents, and access to related researches due to the researchers' financial conditions.

\section{REFERENCES}

Angelovska, N. (2019). Top 5 Online Retailers: "Electronics And Media" Is The Star Of E-commerce Worldwide. Retrieved July 19, 2019, from https://www.forbes.com/ sites/ ninaangelovska/2019/05/20/top-5-online-retailerselectronics-and-media-is-the-star-of-e-commerceworldwide/\#1 c257e3c1cd9

Arif, M. E. (2019). The Influence of Electronic Word Of Mouth (EWOM), Brand Image, and Price on Re-Purchase Intention of Airline Customers. Journal of Applied Management 17(2), 345-356.

Arslan, M., \& Zaman, R. (2014). Impact of Brand Image and Service Quality on Consumer Purchase Intention : A Study of Retail Store in Pakistan. Research on Humanities and Social Sciences 4 (22), 98-106.

Bisrat, N. (2019). Determining Factors Affecting the Adoption of E-Commerce in the Perspectives of Ethiopian Banks (Master's Thesis, Addis Ababa University, Addis Ababa, Ethiopia). Retrieved from http://etd.aau.edu.et/handle/123456789/17142

BPS. (2019). Ekonomi Indonesia 2018 Tumbuh 5,17 Persen. Retrieved July 27, 2019, from https:// www.bps.go.id/pressrelease/2019/02/06/1619/ ekonomi-indonesia-2018-tumbuh-5-17-persen. html

Che, J. W. S., Cheung, C. M. K., \& Thadani, D. R. (2017). Consumer Purchase Decision in Instagram Stores : The Role of Consumer Trust. In Proceedings of the 50th Hawaii International Conference on System Sciences, 24-33. Waikoloa: University of Hawai'i at Mānoa. https://doi.org/ 10.24251/HICSS.2017.004.

Daniel, W. (2019). Wow! Transaksi e-Commerce RI 
2018 Capai Rp 77 T, Lompat 151\%. Retrieved July 19, 2019, from https://www.cnbcindonesia.com/fintech/20190311101823-37-59800/ wow-transaksi-e-commerce-ri-2018-capairp-77-t-lompat-151.

Databoks. (2020). Tren Pengguna E-Commerce Terus Tumbuh. Retrieved December 8, 2020, from databoks.katadata.com

Detiknet. (2019). Pengguna Internet Indonesia Didominasi Milenial. Retrieved August 22, 2019, from https://inet.detik. com/telecommunication/d-4551389/ pengguna-internet-indonesia-didominasi-milenial

Fadlurrohman. (2018). Influencing Property Buying Decision: A Study of Residential Property of PT. Nusa Indah Pratama (Bachelor's Thesis). President University, Cikarang, Indonesia.

Gunawan, A. V., Linawati, Pranandito, D., \& Kartono, R. (2019). Factors That Influence Purchase Decision in E-Commerce in Jakarta and Tangerang. Binus Business Review 10(1), 21-29. https://doi.org/10.21512/bbr.v10i1.5379

Ibrahim, S., Suki, N. M., \& Harun, A. (2014). Structural Relationships Between Perceived Risk and Consumers Unwillingness to Buy Home Appliances Online with Moderation of Online Consumer Reviews. Asian Academy of Management Journal 19(1), 73-92.

JakartaPost, T. (2019). Indonesia has 171 million internet users: Study. Retrieved July 19, 2019, from https://www. thejakartapost.com/life/2019/05/18/ indonesia-has-171-million-internet-users-study. $\mathrm{html}$

Javadi, M. H. M., Dolatabadi, H. R., NourbakHsih, M., Poursaeedi, A., \& Asadollahi, A. R.( 2012). An Analysis of Factors Affecting on Online Shopping Behavior of Consumers. International Journal of Marketing Studies 4(5), 81-98. https:// doi.org/10.5539/ijms. v4n5p81

Jonsson, E., Källström, P., \& Wallander, E. (2019). Why do we purchase from e-retailers? - An explanatory study of the e-loyalty antecedents impact on consumers purchase intentions on the e-commerce market (Bachelor's Thesis, Linnaeus University, Växjö, Sweden). Retrieved from http://lnu.diva-portal.org/smash/record.jsf? pid=diva2\%3A1324871\&dswid=4202.

Kan, M.P.H. \& Fabrigar, L.R. (2017). Theory of Planned Behavior. Encyclopedia of Personality and Individual Differences. Retrieved December 16, 2020, from link.springer.com/referenceworke ntry/10.007\%2F978-3-319-28099-8 1191-1

Khairunnisa, S., Hafidhuddin, D., \& Tanjung, H.(2018). Online Purchase Intention: Study Case Moslem (Islamic) Fashion (Hijup.Com). International Journal of Accounting, Finance and Business 3(16), 35-47.

Khuong, M. N., \& Duyen, H. T. M. (2016). Personal Factors Affecting Consumer Purchase Decision towards Men Skin Care Products - A Study in Ho Chi Minh City, Vietnam. International Journal of Trade, Economics and Finance 7(2), 44-50. https://doi.org/10.18178/ijtef. 2016.7.2.497

Kompas.com. (2019). 80 Persen Konsumen Belanja Online Orang Muda dan Wanita. Retrieved December 16, 2020, from https://lifestyle.kompas. $\mathrm{com} / \mathrm{read} / 2018 / 03 / 22 / 155001820 / 80$-persenkonsumen-belanja-online-orang-muda-danwanita?page $=$ all

Koohikamali, M., Mousavizadeh, M., \& Peak, D. (2019). Continued Usage and Location Disclosure of Location-Based Applications : A Necessity for Location Intelligence. In Proceedings of the 52nd Hawaii Internqational Conference on System Science, pp.1362-1372. Honolulu: University of Hawai'i at Mānoa. Retrieved from https://hdl. handle.net/10125/59577

Mazhar, F., Jam, F. A., \& Anwar, F. (2012). Consumer trust in e-commerce : A study of consumer perceptions in Pakistan. African Journal of Business Management 6(7), 2516-2528. https://doi.org/ 10.5897/AJBM11.080

Meyliana, Fernando, E., \& Surjandy. (2019). The Influence of Perceived Risk and Trust in Adoption of FinTech Services in Indonesia. Communication and Information Technology Journal 13(1), 31-37.

Nguyen, T. H., \& Gizaw, A. (2014). Factors that influence consumer purchasing decisions of Private Label Food Products A case study of ICA Basic (Bachelor's Thesis, Mälardalens högskola Eskilstuna Västerås, Västerås, Sweden). Retrieved from https://www.diva-portal.org/smash/ get/ diva2:705384/fulltext01.pdf

Nugraha, R., Komalasari, F., \& Dethionia, S. (2018). Customer Perception on Prulink Product Purchase Decision : A Case of Greater Jakarta Area. Jurnal Manajemen Indonesia 18(2), 126-143.

Puspitasari, N. B., Nugroho, W. P. S., Amyhorsea, D. N., \& Aries, S. (2018). Consumer's Buying Decision -Making Process in E-Commerce. In The 2nd International Conference on Energy, Environmental and Information System. EDP Sciences 31, 1-6. https://doi.org/https://doi. org/10.1051/e3sconf/20183111003

Putra, D.A. (2019). Mayoritas Kue E-commerce Masih Dinikmati Masyarakat Jabodetabek. Retrieved December 16, 2020 from https://www. merdeka.com/uang/ mayoritas-kue-e-commercemasih-dinikmati-masyarakat-jabodetabek.html

Rachbini, W. (2018). The Impact of Consumer Trust, Perceived Risk, Perceived Benefit on Purchase Intention and Purchase Decision. International Journal of Advanced Research 6(1), 1036-1044. https://doi.org/10.21474/IJAR01/6317

Rafsandjani, R. F. (2018). Analyzing the Effect of Trust and Perceived Value on Purchase Intention. Management and Economics Journal 2(1), 71-84.

Rahi, S., Ghani, M. A., \& Ngah, A. H. (2020). Factors propelling the adoption of internet banking: the role of e-customer service, website design, brand image and customer satisfaction. International Journal of Business Information 
Systems 33(4), 1-21. https://doi.org/10.1504/ IJBIS. 2020.10020858

Robbins, S.P., \& Judge, T. (2007). Organizational Behavior. New Jersey: Pearson Prentice Hall.

Sindo, K. (2019). Indeks E-Commerce Indonesia Masih Rendah. Retrieved April 29, 2020, from https://ekbis.sindonews.com/ berita/1476208/34/ indeks-e-commerce-indonesia-masih-rendah

Sozer, E. G., \& Civelek, M. E. (2018). The Effect of Perceived Benefit on Consumer Based Brand Equity in Online Shopping Context. Ege Academic Review 18(4), 711-725. https://doi.org/10.21121/ eab.2018442989

Statista.com. (2020). Global Retail e-Commerce Market Size 2014-2021, from https://www.statista. com

Suhaily, L., \& Darmoyo, S. (2017). Effect of Product Quality, Perceived Price and Brand Image on Purchase Decision Mediated by Customer Trust (Study on Japanese Brand Electronic Product). Jurnal Manajemen 21(2), 179-194..

Syarizka, D. (2019). Tumbuh Pesat, 8\% Penjualan Ritel 2018 adalah Belanja Online. Retrieved July 19, 2019, from https://teknologi.bisnis.com/ $\mathrm{read} / 20190207 / 266 / 886133 /$ tumbuh-pesat-8-penjualan-ritel-2018-adalah-belanja-online.

Tanadi, T., Samadi, B., \& Gharleghi, B. (2015). The Impact of Perceived Risks and Perceived Benefits to Improve an Online The Impact of Perceived Risks and Perceived Benefits to Improve an Online Intention among Generation-Y in Malaysia. Asian Social Science 11(26), 226-238. https://doi. org/10.5539/ass. v11n26p226

Tashandra, N. (2018). Hati Hati Kena Tipu Saat Belanja Online Simak Dulu Tips Ini. Retrieved June 15, 2020, from https://lifestyle.kompas.com/ $\mathrm{read} / 2018 / 03 / 10 / 150000620 /$ hati-hati-kena-tipusaat-belanja-online-simak-dulu-tips-ini.

Tempo.co. (2019). Survei Pengguna Internet Terbesar, Jakarta Hanya Urutan Ketiga. Retrieved August 22, 2019, from https://tekno. tempo.co/read/1207647/survei-penggunainternet-terbesar-jakarta-hanya-urutan-ketiga/ full\&view $=$ ok

Torlak, O., Ozkara, B. Y., Tiltay, M. A., Cengiz, H., \& Dulger, M. F. (2014). The Effect of Electronic Word of Mouth on Brand Image and Purchase Intention : An Application Concerning Cell Phone Brands for Youth Consumers in Turkey. Journal of Marketing Development and Competitiveness 8(2), 61-68.

Truong, N. X. (2018). The Impact of Hallyu 4.0 and Social Media on Korean Products Purchase Decision of Generation C in Vietnam. Journal of Asian Finance Economics and Business 5(3), 81-93.

Wang, Y., \& Tsai, C. (2014). The Relationship between Brand Image and Purchase Intention: Evidence from Award Winning Mutual Funds. The International Journal of Business and Finance Research 8(2), 27-40.

Wicaksono, B. D. (2019). IMR 2019: Begini Kebiasaan Millennial saat Belanja Online. Retrieved June 15, 2020, from https://www.idntimes.com/tech/trend/ bayu/survei-ims-2019-kebiasaan-millennial-saatbelanja-online-ims $2019 / 5$

Zamrudi, Z., Suyadi, I., \& Abdillah, Y. (2016). The Effect of Social Commerce Construct and Brand Image on Consumer Trust and Purchase Intention. Profit: Junral Administrasi Bisnis 10(1), 1-13. https://doi.org/10.9876/10.9876/ VOL1ISSN1978-743X 